\title{
INTRODUCTION TO QIYAS AND MASLAHAH MURSALAH AND ITS APPLICATION IN THE FUTURE
}

\author{
Remiswal1 ${ }^{1}$ Ayu Anggraini' ${ }^{2}$, Asma Boti' ${ }^{3}$, Zerly Nazar ${ }^{4}$ \\ State Islamic University of Imam Bonjol Padang ${ }^{123}$ \\ NSW Department of Education-NSW Government ${ }^{4}$ \\ Email: remiswal@uinib.ac.id1, Email:Ayuanggraini423@gmail.com1 \\ Email:asmaboti888@gmail.com³,Email:Zerly.Nazar@det.nsw.edu.au ${ }^{4}$
}

\begin{abstract}
This paper discusses qiyas and maslahah mursalah. The goal is to make it easier for us to establish a law. The data collection method that the writer uses is a literature study in the form of searching for books related to qiyas and maslahah mursalah. Qiyas In language (Arabic) means measuring, knowing the size of something, comparing, or equating something with another. For example قدت اللوب بالنراع which means "I measure clothes in cubits." According to Ushul Figh terminology, as stated by Wahbah al-Zuhaili, qiyas is connecting or equating the Law of something with no legal provisions with legal provisions there is Illat similarity between the two. The meaning of Maslahah in Arabic means "actions that encourage human goodness." This article uses the induction and deduction methods and the descriptive analysis approach by conducting a literature study. The result shows that Allah decreed all the laws to his servants in orders/prohibitions containing Maslahah and benefits. The specialty of this paper is that it is written in detail based on arguments so that it is easy to understand. Qiyas and maslahah mursalah are very important for us to understand more deeply to determine an appropriate law. Maslahan Mursalah is an extension of qiyas if there are no more arguments that can support qiyas.
\end{abstract}

Keywords: Qiyas, Muslahah Mursalah, law establishment

\begin{abstract}
Abstrak
Artikel ini membahas tentang qiyas dan maslahah mursalah. Tujuannya untuk memudahkan dalam membuat undang-undang. Metode pengumpulan data yang digunakan adalah studi kepustakaan berupa pencarian kitab-kitab yang berhubungan dengan qiyas dan maslahah mursalah. Qiyas dalam bahasa (Arab) berarti mengukur, mengetahui ukuran sesuatu, membandingkan, atau menyamakan sesuatu dengan yang lain. Misalnya اللوب بالنراع yang artinya "Aku mengukur pakaian dalam hasta". Menurut istilah Ushulfiqh, sebagaimana dikemukakan oleh Wahbah al-Zuhaili, qiyas adalah menghubungkan atau menyamakan hukum sesuatu yang tidak ada ketentuan hukumnya dengan ketentuan hukumnya terdapat kesamaan illat antara keduanya. Arti Maslahah dalam bahasa Arab berarti "perbuatan -perbuatan yang mendorong kebaikan manusia". Artikel ini menggunakan metode induksi dan deduksi serta pendekatan analisis deskriptif dengan melakukan studi kepustakaan. Hasil penelitian ini menunjukkan bahwa Allah menetapkan segala hukum kepada hamba-hamba-Nya dalam perintah/larangan yang mengandung maslahah dan kemaslahatan. Keistimewaan makalah ini adalah penulisannya secara detail
\end{abstract}


berdasarkan argumentasi sehingga mudah dipahami. Qiyas dan Maslahah Mursalah sangat penting untuk dipahami lebih dalam untuk menentukan hukum yang tepat. Maslahan Mursalah merupakan perpanjangan dari qiyas jika tidak ada lagi dalil yang dapat mendukung qiyas.

Kata kunci: Qiyas, Muslahah Mursalah, pembentukan hukum

\section{INTRODUCTION}

The Qur'an, Hadith, Ijma', and Qiyas are some of the sources of the Islamic Law that scholars agree on (Muttafaq), although others are still in dispute (Mukhtalaf). Those who are still in dispute (Muktalaf) of the scholars besides the four sources of Law above, namely istihsan and maslahah mursalah. Qiyas is connecting or equating the Law of something that has no legal provisions with something that has legal requirements because there is an equation 'Illat between the two. maslahah mursalah is to use the principle of benefit (goodness) to establish Islamic Law.

In the terminology of Ushul Figh scholars, Qiyas means looking for similarities between two events using the method deduction (analogical deduction), that is create/draw a legal line new from the old legal line, to use the new legal line on a situation, because of that new line of law there is an equivalent of 'illat with the line of law' which is old. 2 or in another sense, qiyas is the result of thinking "by analogy" deductive". One example of setting law by way of qiyas, namely drinking narcotics is a necessary act determined by law, while there is no found a text that can be used as a legal basis. Thus, to determine the law can be taken Qiyas way by looking for other actions which have been determined by law based on the text, namely the act of "drinking" forbidden wine." That prohibition is firmly and clearly stated in the texts (Surat al-Maidah: 90), with 'illat deed' it's intoxicating.

Between taking narcotics and drinking khamr has the equivalent of 'illat, that is samasama' result in "intoxicating" the drinker so that could damage sense". Based on 'illat' equation that, then set drink narcotics that is haram as it is forbidden to drink alcohol. $\mathrm{n}$ the above case of doing qiyas, that is, conclude using analogical. The reason for this kind of law is rational, so that many events (cases) can be qiyased to other cases if the rationale that's pretty self-explanatory. Qiyas pushes Muslims to think logically in comparing (equating) various cases, in terms of reasons and as a result.

To note, the use of qiyas is only allowed if not obtained on an incident/event it's legal from the texts (Qur'an and Hadith) and ijma'. Therefore, qiyas is one of the flexible sources of Islamic law and relevant in expanding the area of limited validity (nash-nash), and able to solve problems newly developed in society. This is due to the 'illat in qiya' can 
be developed or customized with the problem to be set legal provisions/certainties based on 'illat that already has provisions' the law.

Current developments allow many things that have not been regulated in sources of Islamic law and open up the possibility for scholars to use qiyas as a solution. More so in the future with a more challenging era and many things that of course have not been regulated in the Qur'an and Hadith. This study uses a conceptual approach that considers maslahah mursalah in ijtihad to determine the law (qiyas).

\section{RESEARCH METHODS}

The data collection method that the writer uses is a literature study in the form of searching for books related to qiyas and maslahah mursalah. A library study is a study used to collect information and data with the help of various materials in the library such as documents, magazine books, historical stories, and others. The author conducted a study of alMustasfa's book, which is the masterpiece of Imam al-Gazali. This book addresses qiyas and Maslahah Mursalah, which describes the different applications and their relationship with Maqasid Shari'a in conjunction with Abdul Karim Zaidan's book al-Wajiz fi Usul al-Fiqh, which explains the role of qiyas in legal istinbath and maslahah mursalah concerning its application in contemporary problems. Literature study also means data collection techniques by reviewing books, literature, notes, and various reports related to the problem. Meanwhile, according to other experts, a literature study is a theoretical study, references, and other scientific literature about culture, values, and norms developed in the social situation under study (Mardalis, 1995: 40).

The data analysis technique used in this discussion is the content analysis method. This analysis is used to obtain valid inferences and can be re-examined based on the context (Krippendorff \& Wajidi, 1980: 33-34) In this analysis, the process of selecting, comparing, combining, and selecting various definitions will be carried out until relevant ones are found. By performing the method of induction and deduction, an overview of the implications of qiyas and maslahah mursalah can both interact and support each other. To maintain the recitation process and prevent and overcome misinformation (humane errors that can occur due to a shortage of literature writers), check between libraries and pay attention to supervisor comments (Mardalis, 1995: 70).

\section{DISCUSSION}

\section{Understanding Qiyas}

In Arabic, qiyas means to measure, know the size of something, compare, or equate something with another. For example قمت اللوب بالنراع which means "I measure clothes in cubits." According to the terminology 
of Ushul Figh, as stated by Wahbah al-Zuhaili, qiyas is connecting or equating the law of something that has no legal provisions with something that has legal requirements because there is Illat equality between the two (Abdel Hay, 2016: 66-67). Ibn Subki Suggests in the book of Jami'u alJawami', Qiyas are (Qaḥțānī, 2003: 113)

$$
\text { هو حمل معلوم على معلوم، لمساواته له في علة حكمه، عند الحامل }
$$

It means: "Connecting something known to something known because of the similarity of the law according to mujtahid that connects".

With almost the same understanding, Abu Zahrah presents the definition of qiyas as follows:

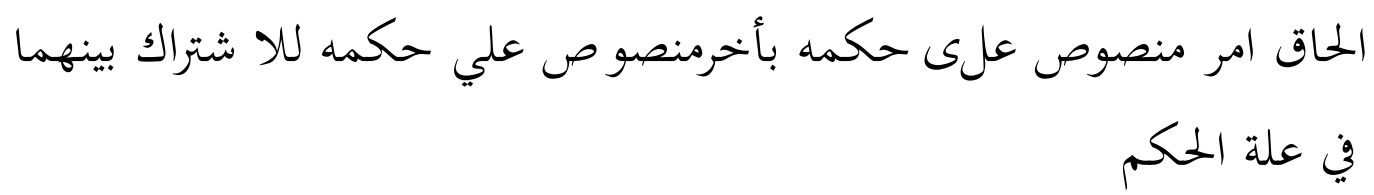

It means: "Connecting a matter that has no nasb about the Law with other things that have a legal nasb because between the two there are similarities in the legal 'illat".

\section{Rukun Qiyas}

A problem can be carried out measurements and equations if it meets the four pillars, namely: (H. A. Syarifuddin, 2008: 32-33)

1. Ashl (الأصل)), is an object that the verses of the Qur'an have determined, hadith of the Prophet (s), or ijma'. For example, the prohibition of Whisky by narrating it to Khamar, then the Ashl is Khamar that has been determined by nash. In the case of Wisky, who carried out measurements and equations on Khamar, then the Ashl is found in the word of God: (QS. Al-Maidah: 90-91).

2. Far'u (الفرع), Is the object to be determined by the law, for which there is no nash or ijma' that is strict in determining the law, as in the case of Whisky above.

3. 'Illat (العلة), is the nature that becomes the motive in determining the Law, in the case of khamar above 'Illatnya is intoxicating.

4. The Law of al-Ashl (حكم الأصل), is the sharia law prescribed by nash or Ijmak' which will be applied to Far'u, such as the prohibition of drinking wine. The ruling set on Far'u is the fruit (result) of qiyas and therefore does not include harmony.

\section{The Power of Reason For The Argument of Qiyas}

Against the blasphemy of qiyas in establishing the sharia law, there is a difference of opinion of the scholars of Ushul Figh. Jumhur Ulama Ushul Figh held that qiyas could be used as a method or means to follow the 
sharia law. In contrast to Jumhur, Muktazilah scholars argue that Qiyas must be practiced in two things only (Qahțānī, 2003: 89-91):

1. 'Mansush's 'illat (mentioned in nash) both in real and by the gesture. For example, in a hadith, the Prophet said:

$$
\text { انما غيتكم عن ادخار لحوم الأضاحي لأجل الدأفة ألا فادخروا }
$$

"I forbade you to keep the sacrificial meat for the sake of al-Daffah (guests from the Bedouin village who came to Medina in need of sacrificial meat), now keep it." (HR. Al-Bukhari, Muslim, Al-Nasai, AlTirmidhi, Abu Dawood and Ibn Majah).

2. In this hadith, the Prophet (PBUH) expressly pointed out that 'illat from the command to store sacrificial meat is for the benefit of the poor Bedouin people who come from their villages to ask for sacrificial meat. When the bedouins no longer need it, then the messenger of Allaah (peace and blessings of Allaah be upon him) allows him to store the meat again. That is, when the 'illat Law is gone, then the law is lost (M. Meirison, 2018: 21).

3. The law of far'u should be more important than the law al-ashl. For example, it is acceptable for both parents to say "ah" to each other because they are both hurtful to both of them. In this relationship, according to them, the beating is heavier than saying "ah" (Sali, 2019: 38).

4. After presenting various opinions of useful fiqh scholars about the reasoning authority of qiyas. Wahbah al-Zuhaili concluded that the opinion could not be sorted into two groups, namely the group that accepts qiyas as a piece of legal evidence embraced by the majority of scholars Usul fiqh, and the group that rejects qiyas as legal evidence, clerics who Shia, al-Nazzam, Zhahiriyyah, and ulama Mu'tazilah from Irak (Ramadhan \& Said Abu al-Futuh al-Bayuni, 2007: 33).

The reasons for the rejection of qiyas as evidence in establishing sharia law are:

1. Their reasons for the Sunnah of the Prophet (PBUH) are found in a narration. The hadith, according to them, shows that something is sometimes obligatory, sometimes haraam, silenced only, and the rulings range between forgiven and mubah (Abdel Hay, 2016: 56).

2. They also reasoned with the attitude of some friends who condemned qiyas, even though some of the other companions remained silent on the friend's reproach. Jumhur Ulama Ushul Figh that allows qiyas as one of the methods in establishing the Law of sharia' suggests several reasons, both from the verses of the Qur'an, Hadits, ijma. The reasons include: 
a. The verse they make an excuse is the word of God in surah Al-Hashr [59]: 2

$$
\text { فَاعتَبِرُوَا يَا أُولِي الََََْْْْارِ }
$$

It means: "So take it as a reminder, you who have eyes."

Say, "Allah is All-Mighty, All-Wise. At the end of the verse, God commands that the Islam people make this story as I'tibar (lesson). Take lessons from an event, according to Jumhur Ulama, including giyas. Therefore, the determination of the Law through qiyas, which Allah calls al-i'tibar, is permissible, even the Qur'an commands it (Ibn 'Aqīl \& Sudays, 2008: 22-23).

Another verse that is used as the reason for qiyas is all verses containing 'Illat as the cause of the emergence of the law. E.g, Surah AlBaqarah [2]: 179

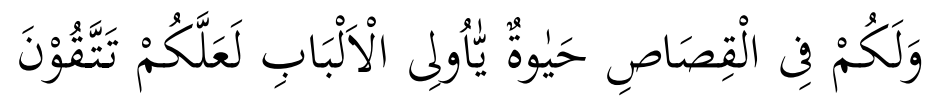

It means: "And in that qishash, there is a reassurance of survival for you, men of understanding, that you may be godfearing." Al-Baqarah[2]:2)

Surah Al-Baqarah [2]: 222

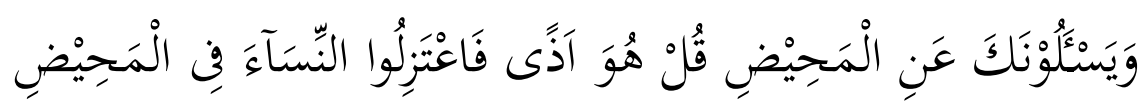

It means: "They ask you (Muhammad) about menstruation. Say, Menstruation is. So keep away from women during menstruation." (QS. Al-Baqarah[2]:222).

According to the Jumhur of scholars, all the verses mention 'illat which is the cause of the emergence of the Law. When there is a case that has no legal provisions in the nash, it is obligatory to look for 'Illat case to compare it with the 'illat law that is in the nash, and if it turns out that 'Illatnya is the same, then the law in the nash can be applied to the case (Ibn 'Aqi1 \& Sudays, 2008: 21-22).

b. The reason for the number of scholars from the hadith of the Prophet PBUH, among others is to use the method of qiyas in answering questions asked to him. Once, someone met the Prophet (s), and he said:

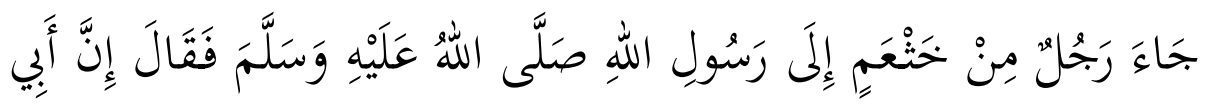

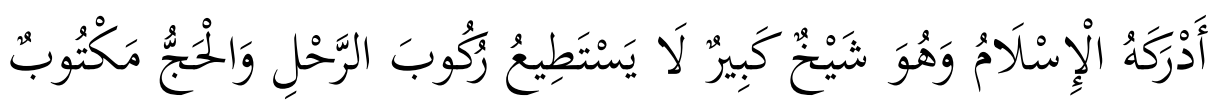




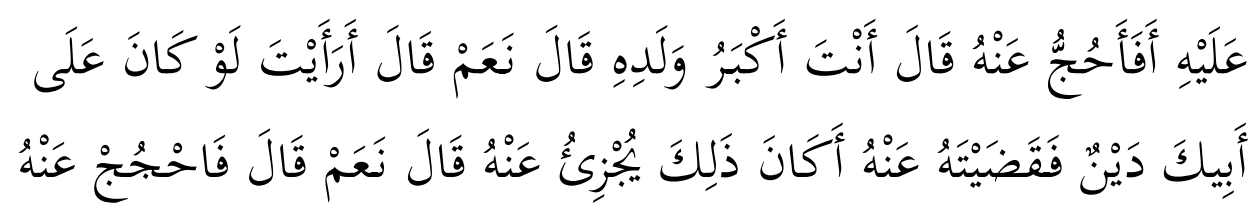

"My father has entered Islam, and he is a very old man so can not afford to ride (camels) to travel to perform the obligatory hajj. Can I recite it?" The Prophet said, "You are the greatest son?" and the man replied, "Yes," and the Messenger of Allah said, "What do you think, if your father had debts to others, then you would pay them, would the debt be paid off?"

c. Another reason stated Jumhur Ulama Ushul Figh is ijma' the companions. In practice, the companions used qiyas, as $\mathrm{Abu} \mathrm{Bakr}$ said about Kalalah, who he thought was a man who did not have a father and son. This view was expressed by Abu Bakr based on his reasoning, and qiyas included the depth of reason (M. Meirison, 2019: 25).

\section{Qiyas Terms Ashl}

Ashl's requirements are (Samarqandi \& Murad, 2004: 67-68):

1. The Law of Ashl is a fixed law that cannot be changed. The ruling is based on shaa';

2. The evidence that stipulates 'Illat on Ashl is extraordinary proof, not general;

3. Ashl was unchanged after doing qiyas;

4. Ashl's Law does not come out of qiyas.

The requirements of law al-ashl's are:

1. It is not specific in the sense that it cannot be developed on far'u. For example, in a narration, it says:

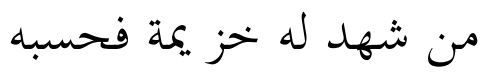

"Khuzaimah's testimony alone is enough"(HR. Abu Dawood, Ahmad ibn Hanbal, al-Hakim, al-Tirmidhi, and Nasa'i)

2. The ruling of al-ashl is not out of the provisions of qiyas. A law that is set differently from the rule of qiyas, then another law is not by the qiyasright in that law. This, according to Wahbah al-Zuhaili, can happen in two ways, namely(M. Meirison, 2017):

3. There is no nash that explains the law of far' $u$, which the law will determine. If the law of al-ashl includes the Law of Ashal on a party and the law of far' $u$ on the other party, then the evidence containing the law of ashl is also a pretext for the Law of far'u. In such cases, qiyas is not required. 
4. Law al-Ashl was first narrated from far'u. In this regard, it is not permissible to qiyas wudhu on tayammum, even if 'Illatnya same, because sharia wudhu' first descended from Sharia tayammum.

The scholars of Ushul Fikih presented four conditions that al-far'u must meet:

1. 'Illat is the same as 'illat in ashl, both in its substance and in its kind.

2. The Law of Ashl does not change after qiyas.

3. The Law of far' $u$ does not precede the Law of ashl. That is, the ruling of Far' $u$ must come then punish Ashl.

4. There is no nash or ijma' that explains the ruling of far' $u$.

'Illat is the most important element in qiyas. Because of the 'illat that determines a law to be stretched to other events. (Kaizal, 2012: 143)

1. Terms and conditions of 'illat:

2. 'It's legal motivation, not just legal signs or indications;

3. 'It's measurable and applies to everyone;

4. 'It's obvious, it's real, and the human senses can capture it. Because 'illat is a sign of the law;

5. 'It's a nature that's by the law;

6. 'Illat is not contrary to nash and ijma';

7. 'It's completely intact and happens reciprocally;

8. 'Illat it does not come later from the law ashl;

9. The Law containing 'Illat does not include the Law of far' $u$;

10. 'Illat is found in Sharia;

11. 'Illat is not at odds with 'other Illats whose position is stronger;

12. When 'illat is converted from nash, then it does not add to the nash itself.

13. 'It can be established and applied to other legal cases.

\section{Division of Qiyas}

The scholars of Ushul Figh suggest that qiyas can be divided into several aspects, namely:

1. Seen in terms of the strength of 'illat contained in the furu' compared to that found in ashl. In this sense, qiyas is divided into three forms, namely (M. Meirison, 2019: 34):
a. Qiyas al-Aulawi (القياس الأولوي)

That is qiyas whose ruling in Furu' is stronger than the law of ashl because 'illat contained in Furu'is stronger than the law of ashl, because 'illat contained in Furu' is stronger than that in ashl. Qiyas Al-Musawi (القياس المساوي)

That is, the Law in Furu' is the same quality as the Law in the ashl because the quality of 'Illat on both is also the same.

b. Qiyas al-Adna (القياس الأدنى)

c. That is, 'illat in Furu' is weaker than 'illat in ashl. 
2. In terms of the clarity of 'illat' in the law, qiyas is divided into two kinds

a. Qiyas al-Jaliy (القياس الجلي)

Namely, Qiyas, whose 'illat is determined by nash together with norm Ashl, or nash does not specify 'Illat his, but there is certainly no difference between ashl and furu'.

b. Qiyas al-Khafiy (القياس الخفي)

That is qiyas whose 'illat is not mentioned in the nash.

3. Judging from the harmony of 'illat with the law, qiyas is divided into two forms:

a. Qiyas al-Mu'atstsir (القياس المر)

Namely, qiyas that connects ashl with fur'u is determined through ijma' or qiyas, which 'ain nature (nature itself) that connects Ashl with Furu' affects the Law itself.

b. Qiyas al-Mula'im (القياس الملام)

It is qiyas whose rulings on Ashl have a harmonious relationship.

4. Seen in terms of whether or not 'illat is explained in the qiyas. Qiyas can be divided into three forms (Sali et al., 2020: 34):

a. Qiyas al-Ma'na (قياسا المعنى)

That is what is not explained 'Illat his, but between Ashl and Furu' can not be distinguished so that Furu' as if ashl.

b. Qiyas al-'Illat (قياس العلة)

Qiyas explained 'Illat his and 'Illat itself is a motivation for the Law of Ashl.

c. Qiyas al-Dalalah (قياس الد لالة)

The qiyas whose 'illat is not the driver of the decree itself, but 'illat is a necessity that guides the existence of 'illat.

5. Seen in terms of method (Masalik) in determining 'illat, qiyas can be divided into (H. F. Meirison, 2020: 68):

a. Qiyas al-Ikhalah (قيائي الأخاله). That is the illat which reasonable, and Ikhalah determines.

b. Qiyas al-Shabah (قياس اشبه)

c. That is, the 'Illat is determined by the al-Asybah method.

d. Qiyas al-Sibru ( قياس السبر). That is, the 'illat is determined by the method of al-sibr wa al-taqsim.

e. D. Qiyas al-thard (قياس الطرد)

\section{Mashlahah Mursalah}

\section{Understanding Mashlahah}

Maslahah is derived from the word shalahah with the addition of "Alif' in the beginning, which means "Good", opposite of the word "Bad" or "Broken". It is Mashar with the word"Shalah." That is the benefit or the benefit of the damage (M. Meirison, 2017: 45). 
The meaning of maslahah in Arabic means "Deeds that encourage the good of man". All the laws that God has appointed to his servants in the form of orders/prohibitions containing Maslahah and benefits. For example, Allah commands us to pray for its benefits to get spiritual tranquility and physical hygiene. There is an opinion of the scholars on the matter: Some argue that God sets the law not to bring benefit, but merely Iradat and its nature

Some scholars think that God's purpose to set the Law on his servant is to bring benefits to his servant because of his affection, so he wants his servant always to be there and benefit. And the opinions of the (Hallāf, 2003: 89-90):

a. Al-Ghazali is the one who brings benefits and keeps his essential youth away is

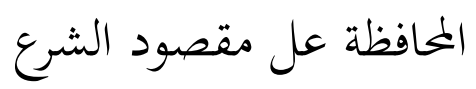

"Maintaining the purpose of the terms" (in establishing the Law). The purpose of Shara"establishes the Law there are five (Keeping Religion, soul, reason, descendants, and property".

b. Al-khawaraisma gives definition the same hamper as al-Ghazali

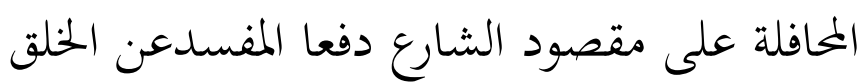

"Keeping the purpose of Shara (by establishing the Law) by avoiding damage from humans".

c. Al-lezh ibn Abdi al-salam in his book qawaid al-ahkam, meaning maslahah in its essential form with pleasure and pleasure form Majazi is "causes that bring pleasure and pleasure. Yusuf Hamid in the book of al-Maqashid, explains the specialty of Maslahah Sharia is compared to maslahah in the general sense as follows (Desmadi Saharuddin et al., 2019: 47):

\section{Various Maslahah}

As explained above, maslahah, in the sense of Shara' 'not only considers reason in assessing the good of something, nor bring pleasure and avoid damage; but further than that. That is what is considered reasonable by reason must also be in line with the purpose of Shara' in establishing the Law that is to maintain the five main principles of life, for example, prohibited wine/liquor. Can be seen in terms of the level of needs and guidance of human life (Hallāf, 2003: 155):

a. In terms of its power

1) Dharuriyah problem

The meaning is the benefit that is needed by human life. This means that human life on the world above this world has no meaning what" if one wrote from the principle of the five there is no which five are religion, soul, reason, heredity, and treasures 
(Samarqandi \& Murad, 2004: 115). Therefore Allah commanded man to make efforts for basic needs. In this case, Allah forbids apostasy to keep Religion, forbidden to kill to preserve the soul, prohibited liquor to keep the mind, forbidden to commit adultery to keep offspring, and forbidden to steal to maintain the property (M. Meirison, 2019: 27).

2) Maslahah Hajiyah

The benefit of the level of human life needs to him is not at the level of dharuri; for example, studying Religion to establish the Religion, eating for survival, sharpening the brain to the perfection of reason, and making a trade to get property. All of this is a good deed.

3) Tahsiniyah problem

Maslahah Hajiyah is the necessity of human life does not reach the level of dharuri nor to the level of hajj" but the need must be fulfilled to provide perfection and beauty for human life. Jihad in the way of Allah, to uphold religion even at the expense of life and property as it is in the word of Allah letter Al-Maidah (5):41 "And strive hard with your wealth and your lives, and do not be of those who believe". The point is to show the necessity to put Religion above the soul and property. Similarly, sharia allows drinking wine for the suffocating person to release his emergency. This suggests that nurturing the soul must take precedence over stimulating reason.

b. From the harmony. Maslahah is divided into three kinds:

1) Maslahah al-mu'tabarah is a direct or indirect guide from Sharia that gives instructions to maslahah, which is the reason for establishing the law. And maslahah is also divided into three categories:

a) Munasib mu'atstsir. Direct instructions from the making of the law of Shara' that pays attention to the maslahah means there is a guidance Shara' 'in the form of nash and ijma which stipulates that maslahah is made the reason for establishing the law. An example of nash evidence is forbidden to approach menstruating women; the reason for menstruation is this disease is called maslahah because it distances itself from the damage or illness that is associated with the prohibition of approaching women in the name of munasib. Where it is found in Al-Baqarah (2): 222 "They ask you about menstruation, let's say that menstruation is a disease".

b) Munasib Mulaim the meaning is Shara' directly does not set a law mentioned, but there is a guidance Shara' that the situation is set Shara' as an excuse for a similar direction. Examples: 
(1) The continued custody of the father of his daughter because his daughter was "immature".

(2) It is permissible to pray for those who are Muqim (locals) because of the rain.

(3) Establishing the "cold" state to be the reason for the obstacle to Shalat altogether in the Mosque.

2) Maslahah al-Mulghah. Maslahah is considered reasonable by reason, but it is not noticed by shara', and there are instructions that reject it. For example, A king and a rich man break the law and have sex with his wife during the day in the month of Ramadhan for this person, the best signal is to be told to fast two months in a row because this way will make a deterrent not to do so. This consideration is excellent and reasonable even in line with shari'a in establishing the Law. It is what is viewed by reason, in line with the purpose of Shara in establishing the Law, but there is no guidance Shara' that takes it into account, and there is also no guidance Shara' who rejects it (al-Amidi, 2008: 251).

\section{Maslahah Mursalah As Ijtihad Method}

Maslahah mursalah as ijtihad method is that there is no specific evidence that Maslahah is accepted by Syar'i" either directly or indirectly (Sali, 2019: 56). The group that uses maslahah mursalah is not using it unconditionally in the sense that it must be fulfilled to him some conditions. Which is a general condition is that maslahah mursalah is only used when not found in nash as reference material. Special requirements that can be Ijtihad by using maslahah mursalah are:

1. Maslahah mursalah is an essential and general means accepted by common sense that it benefits humans and avoids harm to humans.

2. In the ordinary sense value of an essential Maslahah has been in line with the purpose and purpose of Shara in setting every Law, which causes benefit for man.

3. In establishing the Law does not clash with the evidence Sharathat has existed both in the Qur'an and Sunnah

4. Maslahah mursalah in practice in conditions of need, If Maslahah is not completed in this way, then the people will be in a little life.

The arguments among scholars who use maslahah mursalah are:

1. There is a Takrir (confession) of the Prophet on the explanation of Muadz ibn Jabal who used ijtihad bi al-ra'yi Bilal did not find Qur'an and the sunnah of the Prophet to resolve a legal case.

2. The existence of amaliah and practice is so widespread among the companions of the Prophet about the use of maslahah mursalah as a condition that has been received with friends without blaming each other .e.g. leader election like Abu Bakar as a caliph conducted by the 
Prophet's friend, printing money in the time of Umar bin Khattab, the unification of reading the Qur'an in the time of Uthman.

3. If in certain circumstances to establish the law should not use the method maslahah mursalah will get the people in trouble. Allah desires ease in his servants and avoid difficulties in surah Al Baqarah 2:(185) and the Prophet wants his people to take a more straightforward way in their lives.

Groups of scholars who reject maslahah mursalah as a method of ijtihad:

1. If a maslahah there is a guidance Shara that justifies it or called Muktabarkah, then it has entered qiyas.

2. Doing good deeds from people who do not get recognition in nash will lead to legal experience based on willingness, and according to lust, AlGazali does not accept this.

3. Using maslahah in ijtihad without sticking to nash will result in the emergence of a free attitude in establishing laws that can result in a person being persecuted in the name of the Law.

4. If it is permissible to be Ijtihad with maslahah, who does not get support from nash, it will give the possibility to change the sharia law for reasons of changing time and different places and because of different people with others.

When it is noticed the difference of opinion with each cleric's arguments who accepts and rejects the method maslahah mursalah in ijtihad, there seems to be no difference in principle (H. A. Syarifuddin, 2008: 215).

\section{Relevance of Maslahah Mursalah in the Present and the Future.}

We will have difficulty finding the evidence nash or guidance Shara' 'to subjugate the law from specific problems that arise. For some instances, we will likely have trouble using the qiyas method in establishing the law because it can not be found in nash (Qur'an and sunnah). The distance of time is so far.

In such circumstances, we will deal with some Issues that can rationally be judged good badly to set the Law, still not find legal support from nash. To find a solution so that all acts of The Horn of Muslims can be placed in the religious legal order, maslahah mursalah can be used as an alternative as a basis in being ijtihad. To eliminate (reduce) or eliminate the worry will slip on the attitude of all and at will lust, then in be ijtihad, using maslahah should be done together (A. Syarifuddin, 2012: 98).

\section{CONCLUSION}

This study can be concluded that qiyas is to connect or equate the law of something that has no legal provisions with something that has legal requirements because there is a similarity of illat between them. qiyas can 
be used with pieces of evidence from the Qur'an and Hadith as interpretations in solving contemporary problems. Maslahah mursalah Is the basis of benefits (goodness) used to uphold Islamic Law. Maslahah mursalah does not use nash or verses of the Qur'an and Hadith in its arrangement but must be in line with the spirit of sharia and not contrary to the intent and purpose of sharia itself. Maslahah Mursalah can be used as one of the alternatives as a basis in berijtihad when it is difficult to use the method of qiyas in establishing the law. However, in performing ijtihad using maslahah, it must be done together and consider all aspects comprehensively.

\section{REFERENCES}

\section{Buku-buku}

AbdelHay, M. F. (2016). Usul al-Fiqh rise, developments, Methodologies $\mathcal{E}$ Literature. Dar al-Salam.

al-Amidi, al-A. (2008). Al-Ihkam fi Ushul al-Ahkam.

Hallāf, 'Abd-al-Wahhāb. (2003). 'Ilm uṣūl al-figh. Dār al-ḥadīt.

H.Frazier Moore. Public relation: Building an image with communication. PT Remaja Rosdakarya.

Ibn 'Aqīl, A. al-W. 'Alī, \& Sudays, 'Abd al-Raḥmān ibn 'Abd al-'Azīz. (2008). Al-Wādịh fì ușūl al-figh (al-Ṭab‘ah 1). Maktabat al-Rushd Nāshirūn.

Krippendorff, K., \& Wajidi, F. (1980). Analisis isi: Pengantar teori dan metodologi. Rajawali Pers.

Mardalis. (1995). Metode penelitian: Suatu pendekatan proposal. Bumi Aksara.

Syarifuddin, A. (2012). Garis-garis besar ushul figh. Kencana.

Syarifuddin, H. A. (2008). Ushul figh. Logos Wacana Ilmu.

\section{Jurnal-jurnal}

Desmadi Saharuddin, Meirison, Ilya Chusna, \& Ade Sofyan Mulazid. (2019). Capitulation and Siyasah Syar'iyah Al-Maliyah Impact on Economic Stability of the 18th \& 19th Ottoman Turks. QIJIS (Qudus International Journal of Islamic Studies), 7(2), 329-366. https:// doi.org/10.21043/qijis.v7i2.4847

Meirison, H. F. (2020). Al-Hajat As The Basis of Contemporary Ijtihad. 17(1), 105-121. https:// doi.org/10.24042/adalah.v17i1.6209

Meirison, M. (2017). Implementasi Tanqih Al-Manath dalam Penerapan Hukum. Nizham Journal of Islamic Studies; Vol 2 No 1 (2014): Mazhab Hukum Islam Di Indonesia. https://ejournal.metrouniv.ac.id/index.php/nizham/article/view/868 
Meirison, M. (2018). Riba and Justification in Practice in Scholars' Views. Transformative, 2(1), 348. https:/ / doi.org/10.23971/tf.v2i1.922

Meirison, M. (2019a). Mashlahah dan Penerapannya dalam Siyasah as Syar'iyah. Ijtihad, 32(1). https:/ / doi.org/10.15548/ijt.v32i1.32

Meirison, M. (2019b). Sejarah Kepemimpinan Wanita di Timur Tengah Dalam Tinjauan Hukum Islam (Analisa Terhadap Syajar al Durr). Kafaiah: Journal of Gender Studies, 9(1), 50. https://doi.org/10.15548/jk.v9i1.231

Qaḥṭānī, M. ibn 'Alī. (2003). Manāhij al-futyā fì al-nawāzil al-fiqhīyah almu'ạșirah (1st ed., Vol. 1). Dār al-Andalus al-Khaḍrā' lil-Nashr waal-Tawzī'.

Ramadhan, A. A. A., \& Said Abu al-Futuh al-Bayuni. (2007). Mausu'ah alQawaid al-Fiqhiyah al-Munazamah lil Mu'amalat al-Maliyah alIslamiyah wa Dauruha fi Tauzih an-Nizham al-Mu'ashirah (1st ed., Vol. 1). Dar al-Iman.

Sali, M. A. (2019). Distinction of Justice and Fairness during Umar bin Abdul Aziz's Reign. AJIS: Academic Journal of Islamic Studies, 4(2), 127. https:/ / doi.org/10.29240/ajis.v4i2.954

Sali, M. A., Saharuddin, D., \& Rosdialena, R. (2020). Takhrij Fikih dan Permasalahan Kontemporer. Al-Istinbath: Jurnal Hukum Islam, 5(1), 51. https:// doi.org/10.29240/jhi.v5i1.1235

Samarqandi, M. I.-'Abd-al-Hamīd al-, \& Murad, R. (2004). Al-Mizan fi uṣūl al-figh (Tab`a 1). Dār al-Kutub al-'Ilmīya.

Bay, Kaizal. Metode Mengetahui 'Illat dengan Nash (Alqur'an dan Sunnah) dalam Qiyas. Jurnal Ushuluddin, XVIII (2), 143. 
Remiswal, dkk

Halaman ini sengaja dikosongkan 